ARTIGO

\title{
Aprender a ser professor em contexto de estágio: um estudo com recurso a timelines em entrevistas de natureza biográfica*
}

\author{
Patrícia Maria Silva Gomes' (D) \\ Paula Maria Leite Queirós (D) \\ Paula Maria Fazendeiro Batista' (D
}

\section{RESUMO}

O objetivo do estudo é procurar compreender o papel das experiências emocionais no processo de aprender a ser professor. Seis estudantes-estagiários de educação física construíram timelines com o registo dos momentos do estágio que consideraram significativos para sua aprendizagem e posteriormente foram entrevistados. A análise foi efetuada por recurso aos princípios de codificação da Ground Theory. Os dados evidenciaram que o estágio é marcado por um "choque com a realidade", em que as emoções negativas se sobrepõem às emoções positivas. As experiências positivas, por conferirem confiança e motivação aos estudantes-estagiários, geraram maior envolvimento no processo de aprendizagem. Aprender a ser professor configura-se como um processo de transformação, em resultado do envolvimento emocional, que ocorre pela interação com o contexto e o apoio dos orientadores.

PALAVRAS-CHAVE

processo de aprendizagem; estágio profissional; experiências emocionais; timeline.

\footnotetext{
*Estudo integrado em um projeto de doutoramento financiado pela Fundação para a Ciência e Tecnologia (FCT) subordinado à temática "Como se aprender a ser professor: um estudo longitudinal com estudantes do $2^{\circ}$ ciclo em ensino de educação física nos ensinos básico e secundário", com a referência SFRH/BD/101895/2014.

'Universidade do Porto, Porto, Portugal.
} 


\title{
LEARNING TO BE A TEACHER IN A STUDY CONTEXT: A STUDY USING TIMELINES ON BIOGRAPHICAL INTERVIEWS
}

\begin{abstract}
The study aims to understand the role of emotional experiences in the process of learning to be a teacher. Six Physical Education trainee teachers constructed timelines with the significant moments of their school placement that contribute for their learning and, after this, they were interviewed. The content were analyzed according to the coding principles of Ground Theory. The data evidenced that the internship is marked by a "shock with reality", in which negative emotions overlap the positive emotions. Positive experiences, that give confidence and motivation to trainee teachers, create more involvement in the learning process. Learning to be a teacher is a process of transformation, resulting of the emotional involvement that occurs through interaction with the context and the support of the supervisor.
\end{abstract}

KEYWORDS

learning process; school placement; emotional experiences; timeline.

\section{APRENDER A SER PROFESOR EN CONTEXTO DE ESTADIO: UN ESTUDIO CON RECURSO A TIMELINES EN ENTREVISTAS DE NATURALEZA BIOGRÁFICA}

\section{RESUMEN}

El estudio tiene como objetivo comprender el papel de las emociones en el proceso de aprender a ser profesor. Seis estudiantes-aprentices de educación física construyeron timelines con el registro de los momentos de la etapa que consideraron significativos para su aprendizaje y posteriormente fueron entrevistados. El contenido fue analizado de acuerdo con los principios de codificación de la Ground Theory. Los datos evidenciaron que las prácticas están marcadas por un "choque con la realidad", en el que las emociones negativas se superponen a las emociones positivas. Las experiencias positivas, por conferir confianza y motivación a los estudiantes de prácticas, generaron una mayor participación en el proceso de aprendizaje. Aprender a ser profesor se configura como un proceso de transformación, como resultado de la implicación emocional, que ocurre por la interacción con el contexto y el apoyo de los orientadores.

PALABRAS CLAVE

proceso de aprendizaje; prácticas; experiencias emocionales; timeline. 


\section{INTRODUÇÃO}

Aprender a ser professor é um processo complexo e multifacetado, decorrente da interpretação e da atribuição de significados a novas experiências, sendo influenciado pelas caraterísticas individuais de cada estudante, pelas vivências anteriores à formação (Cornelissen e Van Wyk, 2007) e pela interação com o meio e com outros agentes (e.g., Anh e Marginson, 2013; Geijsel e Meijers, 2005; Goel et al., 2010; MacPhail et al., 2014). Ao longo do percurso formativo para a docência, os conhecimentos, competências, habilidades, atitudes e valores que os estudantes adquirem derivam da apropriação de significados que evoluem ao longo das experiências proporcionadas pelo meio social. Nesse processo, os estudantes podem colocar questões baseados em seus próprios problemas, construindo, desconstruindo e reconstruindo conceitos (Fosnot, 1998). Perante esse entendimento, considera-se que o processo de aprendizagem ocorre quando o estudante se envolve cognitiva e emocionalmente com sua biografia pessoal (Dowling, 2011) e com os diferentes contextos com que contacta, construindo um conhecimento prático na interação com os outros e com o meio. A aquisição de conhecimentos ocorre das transformações ao nível da estrutura mental do estudante, envolvendo a reorganização de perceções e a formação constante de novas relações com o conhecimento, "que resulta não de uma leitura direta da experiência, mas sim [...] da atividade mental construtiva na qual e pela qual as pessoas leem e interpretam a experiência” (Coll, 2000, p. 107).

Aprender a ser professor pode, assim, ser entendido como um processo de construção contínuo do estudante (Fosnot, 1998), que diante de sua biografia (vivências pessoais) e de conceções prévias, quando confrontado com novas experiências na relação com o outro e com o meio, mostra-se capaz de atuar desenvolvendo novos modelos mentais. O processo de aprendizagem, segundo a perspetiva socioconstrutivista de Vygotsky (1896-1934), Luria (1902-1977) e Leontiev (1904-1979), sustenta esse entendimento de aprendizagem. Do ponto de vista da investigação, vários são os estudos que evidenciam essa compreensão (Meijer, Graaf e Meirink, 2011; Timoštšuk e Ugaste, 2010, 2012), apontando para um processo de ensino focado em experiências concretas e contextualmente significativas. Para Vygotsky (1978), todas as atividades cognitivas básicas do indivíduo (funções internas), inerentes à aprendizagem, decorrem de sua história social e são produto do desenvolvimento histórico-social da comunidade em que está inserido (fatores externos). Nesse processo, o estado real de desenvolvimento de cada indivíduo pode ser superado para um plano potencial superior - zona de desenvolvimento proximal $(Z D P)^{1}-$ desde que exista suporte em contextos socialmente estimulantes (Vygotsky, 1978, 1998). Com efeito, e como refere o mesmo autor, aprender

1 ZDP: área potencial de desenvolvimento cognitivo, definida como a distância que medeia o nível de desenvolvimento atual de um indivíduo, determinado pela sua capacidade de resolver problemas autonomamente, e o nível de desenvolvimento potencial, determinado pela capacidade de resolver problemas sob a orientação de outros mais capazes (Vygotsky, 1978). 
implica a existência de alguém mais capaz (que no contexto da formação, particularmente no estágio, são os professores orientadores), que crie pontes e andaimes que ajudem os estudantes a superarem a sua situação real e a progredir para outra de desenvolvimento superior.

A aprendizagem pode, assim, ser vista como uma produção social de significados na relação entre as experiências situadas do indivíduo (Anh e Marginson, 2013) e os novos insights (Goel et al., 2010). Por outras palavras, a aprendizagem decorre de uma interface entre as experiências pessoais dos estudantes e o confronto com o contexto social, cultural e institucional, sendo a construção do "eu" profissional um processo biográfico, cognitivo, relacional e situacional. Biográfico, pela singularidade da história de cada um e de suas múltiplas experiências (Dubar, 1997), o que pressupõe um modo particular de agir, reagir e interagir com os diferentes contextos; cognitivo, pela capacidade de cada um interpretar e atribuir significados às suas vivências, na interação com os outros e com o meio, ao organizar cada experiência com as próprias estruturas lógicas e de entendimentos (Fosnot, 1998); relacional e situacional, pela ligação dialética entre o indivíduo e o contexto social (Vygotsky, 1978), uma vez que a interação social e contextualizada é o que permite ao estudante confrontar-se com os conflitos cognitivos, negociando e desenvolvendo um conjunto de significados e pontos de vista alternativos, que influenciam seus modelos mentais. Por essa razão, analisar os processos mentais do estudante passa por procurar compreender o modo como os conhecimentos e comportamentos mudam e os fatores que estão associados a essas mudanças. Nesse campo, alguns autores (Meijer, Graaf e Meirink, 2011; Schutz et al., 2006; Timoštšuk, Kikas e Normak, 2016; Timoštšuk e Ugaste, 2012) veiculam a importância de associar a análise das experiências emocionais ao processo de aprendizagem dos estudantes, porquanto consideram que aprender é um processo emocionalmente desafiador, com forte impacto no desenvolvimento profissional e pessoal de cada indivíduo (Meijer, Graaf e Meirink, 2011; Timoštšuk e Ugaste, 2012).

\section{O PAPEL DAS EMOÇÕES NA APRENDIZAGEM}

Embora se reconheça um importante papel das emoções nas operações mentais dos professores (Mayer, Salovery e Caruso, 2000), as pesquisas no âmbito da psicologia educacional são ainda pouco representativas (Goetz et al., 2015). Na verdade, pouco se sabe acerca do papel das emoções no processo de aprender a ensinar, nem como as experiências emocionais dos professores se relacionam com suas práticas de ensino ou como o contexto sociocultural interage com as emoções desses profissionais (Sutton e Wheatley, 2003). Outros elementos pouco explorados são o modo como os professores regulam suas emoções, a relação entre as emoções e as motivações, e como essas experiências emocionais podem influenciar o seu desenvolvimento profissional (e.g., Geijsel e Meijers, 2005; Sutton e Wheatley, 2003).

Nias (1996, p. 294) afirma: "nem a cognição nem a emoção podem ser separadas das forças sociais e culturais que as ajudam a formar e que, por sua vez, são por elas 
moldadas". Assim, tal como a aprendizagem, as emoções ${ }^{2}$ emergem de um processo relacional que envolve transações pessoa-ambiente nas diferentes configurações de uma atividade, dependendo tanto de uma dimensão social (interações com o contexto e outros intervenientes) como da representação pessoal, apresentando diferentes implicações na ação dos indivíduos (Schutz et al.,2006). Tal significa que o julgamento ou a avaliação que envolvem a interpretação de uma transação pessoa-ambiente são influenciados pelo significado, pela relevância ou pelas preocupações do indivíduo (Roseman e Smith, 2001 apud Sutton e Wheatley, 2003). Ou seja, as emoções são formas de ser e estar no mundo, que emergem de julgamentos conscientes e inconscientes em relação aos sucessos percebidos, na obtenção de metas ou na manutenção de padrões ou crenças (Schutz et al., 2006). Pode-se, assim, considerar que as emoções são transações que integram contextos sócio-históricos (Sutton e Wheatley, 2003) e podem ser interpretadas como formas socialmente construídas e pessoalmente experienciadas (Schutz et al., 2006). Por essa razão, Franks (2001) argumenta que as emoções vão determinar a escolha de modelos centrais para a identidade profissional docente e o desempenho do professor. Nesse âmbito, Sutton e Wheatley (2003) identificam vários elementos que podem influenciar a ação do professor. Primeiro, enfatizam o poderoso papel das emoções negativas em atrair atenção e foco, bem como os efeitos na memória, por facilitarem a lembrança de experiências intensas; em contrapartida, reforçam que as emoções negativas podem reduzir a motivação intrínseca do professor, ao contrário das emoções positivas. Segundo, sugerem que os professores que experienciam emoções positivas podem gerar mais ideias e estratégias que os ajudam a desenvolver habilidades para a resolução de problemas. Terceiro, os estados emocionais podem influenciar as atribuições para as causas das situações sucedidas (e.g., a raiva promove a atribuição de responsabilidades a outras pessoas e a tristeza, a forças situacionais). No entanto, importa considerar a "avaliação" nesse processo de influência das emoções nas ações dos indivíduos, percebendo que um mesmo evento externo não conduz às mesmas emoções e que é fundamental atender ao papel da cultura na compreensão das emoções (Sutton e Wheatley, 2003).

Diante desse quadro, no contexto da formação de professores, o acesso a uma melhor compreensão do modo como ocorre a aprendizagem de estudantes no decurso do estágio requer perceber como as emoções orientam seus modos de pensar, de decidir, de agir e de interagir (Meijer, Graaf e Meirink, 2011; Timoštšuk, Kikas e Normak, 2016; Timoštšuk e Ugaste, 2012).

\section{O ESTÁGIO ENQUANTO ESPAÇO DE APRENDIZAGEM}

$\mathrm{Na}$ formação inicial de professores, o estágio profissional é considerado uma das etapas mais importantes no processo de aprender a ser professor (Alarcão e

2 Um processo emocional consiste numa rede de mudanças de uma variedade de subsistemas (ou componentes) do organismo, essas componentes incluem a avaliação, a experiência subjetiva, as mudanças fisiológicas, a expressão emocional e as tendências de ação (Sutton e Wheatley, 2003). 
Tavares, 2003; Batista e Queirós, 2013; Lange e Burroughs-Lange, 2017; O’Sullivan, 2003), porquanto permite aos estudantes mobilizarem os conhecimentos e as habilidades adquiridas anteriormente, para a prática diária da escola (Batista e Queirós, 2013). A prática de ensino em contexto real, em resultado do desempenho de papéis profissionais sob orientação de professores experientes, permite incorporar um roteiro sociocultural (e.g., normas, valores, hábitos, costumes e práticas) que concorre para o desenvolvimento de um conhecimento profissional situado (Sirna, Tinning e Rossi, 2010). De facto, é no contexto real de ensino que os estudantes se deparam com conflitos entre o que conhecem e o que encontram, sendo pela interação com o outro e com o meio que acedem a um conjunto de significados que influenciam suas funções internas. A aprendizagem deriva, assim, de práticas sociais contextualizadas, em que os estudantes interagem e participam ativamente em um contexto histórico-social que os ajuda a dar significado às suas ações (Wenger, 1998). Nesse entendimento, aprender a ser professor é vinculado como sendo um processo de tornar-se membro de determinada comunidade (profissional), que implica, acima de tudo, a capacidade de comunicar e agir de acordo com conhecimentos e normas específicas. Esse processo é designado por Sfard (1998) de metáfora da participação - "participar" e "fazer parte" - , visto que envolve o movimento do estudante-estagiário de uma participação mais periférica para uma participação mais central (legítima), em que o estudante se sente capaz de participar ativamente nas práticas sociais do grupo, modificando e adaptando suas aquisições ao contexto. Ou seja, os estudantes tendem a mover-se de uma participação periférica para uma participação plena, que Lave e Wenger (1991) designam de "participação periférica legítima”.

É com base nesse entendimento que vários autores (Macphail et al.,2014; Ten Dam e Blom, 2006; Timoštšuk e Ugaste, 2010) consideram a constituição de comunidades de prática $^{3}$ importante no processo de formação inicial. Nesses espaços, de partilha e cooperação entre pares (núcleo de estágio), destaca-se o papel fundamental de um membro mais experiente: o professor cooperante ${ }^{4}$ (Alarcão e Tavares, 2003; Batista e Queirós, 2013), que assume tarefas fundamentais no suporte aos estagiários. Weiss e Weiss (2001, p. 134) reforçam a influência marcante do professor cooperante, afirmando que "os professores cooperantes são aqueles que mais influenciam a qualidade da experiência formativa do estudante-estagiário e moldam frequentemente $o$ que eles aprendem no modo como os orientam". Nesse âmbito, alguns aspetos positivos na relação que se estabelece entre esses agentes parecem sobressair, tais como o apoio emocional, biográfico e formativo do professor cooperante (Cardoso, Batista e Graça, 2016), sendo que as boas relações interpessoais podem facilitar e favorecer a aprendizagem dos estudantes-estagiários. Por essa razão, importa encarar a supervisão como uma prática interativa e colaborativa, em que o professor cooperante passa a ser

3 As comunidades de prática são aqui entendidas como a vivência em contexto real de prática profissional, em um grupo seletivo de pessoas que partilham experiências e configuram propósitos, de acordo com interesses comuns (Lave e Wenger, 1991).

$4 \mathrm{O}$ professor cooperante está presente diariamente na escola cooperante, garantindo a orientação e a supervisão dos estudantes-estagiários no decorrer das atividades de estágio profissional. 
cada vez menos um modelador da prática e cada vez mais um coconstrutor da prática (Clarke, Triggs e Nielsen, 2014), realizando um acompanhamento consubstanciado não apenas na reflexão do "quê"e do "como", mas também do "porquê da prática". Esse processo permitirá ao estudante-estagiário aceder a níveis de pensamento e padrões de ação superiores, com reflexos no processo de aprendizagem e, consequentemente, na transformação do estudante em uma pessoa diferente (Illeris, 2014).

Aprender a ser professor carateriza-se, portanto, por um permanente envolvimento pessoal, relacional e situacional, em que as experiências emocionais emergem inevitavelmente relacionadas com os papéis e funções inerentes à profissão, experienciados pela primeira vez em contexto de estágio. As experiências emocionais dos estudantes-estagiários intensificam as experiências de ensino vivenciadas no estágio profissional, requerendo a capacidade de pensar, agir, integrar e aplicar habilidades em situações e condições diferentes e com grupos e pessoas distintas (Timoštšuk, Kikas e Normak, 2016; Timoštšuk e Ugaste, 2012).

Nesse contexto, o presente estudo tem como propósito central procurar compreender o papel das emoções no processo de aprender a ser professor de estudantes-estagiários. Especificamente, pretende-se dar resposta às seguintes questões:

1. Que experiências emocionais marcam os estudantes-estagiários na primeira etapa do estágio?

2. Quais as dificuldades que os estudantes-estagiários identificaram na fase inicial do estágio e como as superaram?

3. Como é que os estudantes-estagiários percecionam as experiências emocionais no processo de aprender a ser professor?

\section{METODOLOGIA}

\section{CONTEXTO DO ESTUDO E PARTICIPANTES}

Participaram no estudo seis estudantes-estagiários (quatro do sexo feminino e dois do sexo masculino, com idade compreendida entre 22 e 23 anos), do $2^{\circ}$ ciclo em ensino de educação física nos ensinos básico e secundário, da Faculdade de Desporto da Universidade do Porto (FADEUP), do ano letivo 2013-2014. Na FADEUP, a unidade curricular de estágio profissional acontece no segundo ano do curso $\left(3^{\circ} \mathrm{e}\right.$ $4^{\circ}$ semestres) e incorpora duas componentes: a prática de ensino supervisionada e o relatório de estágio profissional. A prática de ensino supervisionada estrutura-se em três áreas de desempenho:

1. Organização e gestão do ensino e da aprendizagem: conceção, planeamento, realização e avaliação do processo de ensino-aprendizagem em educação física;

2. Participação na escola e relações com a comunidade: colaboração nas atividades do plano da escola e no desporto escolar; e

3. Desenvolvimento profissional: participações em formações, conferências, seminários e elaboração de um estudo de investigação-ação. 
O estágio profissional decorre em núcleos de estágio constituídos por dois a quatro estudantes-estagiários, supervisionados por um professor cooperante da escola e um orientador da faculdade. Neste estudo, os participantes pertenciam a núcleos de estágio distintos, de escolas situadas na região do grande Porto.

\section{PROCEDIMENTOS DE RECOLHA}

A recolha de dados foi efetuada por recurso a uma entrevista de tipo biográfico, conduzida pelo método Timeline Interview, em que o entrevistado é convidado a representar visualmente os acontecimentos que considera significativos para o seu processo de aprendizagem. Os benefícios do uso desse tipo de entrevista biográfica centram-se na possibilidade de vincular as atividades de aprendizagem com outros acontecimentos no espaço e no tempo (Adriansen, 2012). Para o efeito, no decorrer do primeiro semestre do estágio profissional, especificamente no primeiro período letivo (2013/2014) do ensino básico e secundário, os estudantes-estagiários foram convidados a preencher uma linha do tempo com escritos e/ou desenhos relativos ao vivenciado nesse período, tendo por base três grandes temas: emoções, dificuldades e aprendizagens (ver exemplo na Figura 1).

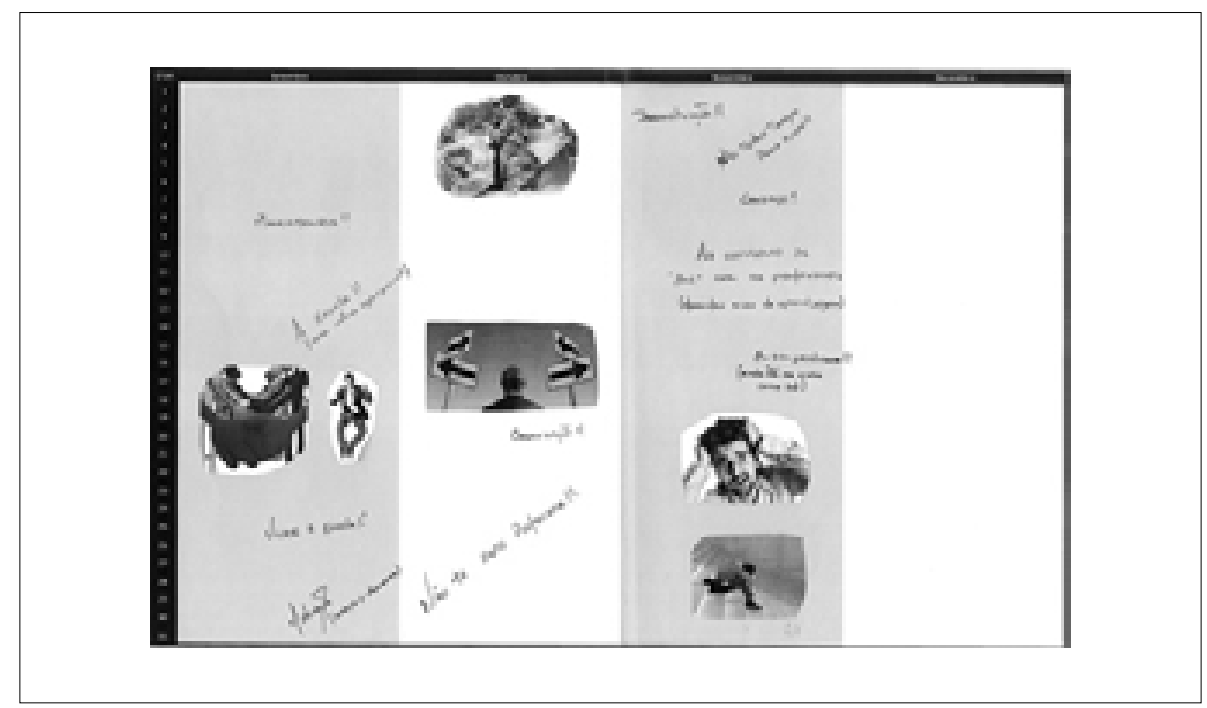

Figura 1 - Timeline de João.

Elaboração das autoras.

No término dessa etapa de estágio profissional foi conduzida uma entrevista atendendo a duas fases: exploração aberta dos registos efetuados, para permitir aos participantes expressarem livremente os seus pontos de vista (Leung, 2010); e uma entrevista semiestruturada, tendo por base as atividades desenvolvidas no estágio profissional e aprendizagens adquiridas, aprofundando assim os dados emergentes da timeline. Aqui o importante não era a forma como as histórias eram contadas, mas, principalmente, a forma como as histórias se relacionavam com o que acon- 
tecia na vida dos entrevistados e como reagiam em relação à mesma (Adriansen, 2012). Ambas as etapas de entrevista foram sujeitas à gravação de áudio e objeto de anotações em caderno relativas à postura dos entrevistados, hesitações ou outras ações visualmente relevantes durante o seu discurso.

O presente estudo teve parecer favorável da Comissão de Ética da FADEUP (CEFADE 07/2012), tendo sido solicitado a cada participante uma declaração de consentimento livre e informado, bem como assegurado o anonimato pela utilização de nomes fictícios.

\section{PROCEDIMENTOS DE ANÁLISE}

A análise dos dados foi efetuada em duas etapas distintas: na primeira foram reunidas as seis timelines e as entrevistas foram transcritas integralmente; na segunda, ambas as fontes de informação (timelines e entrevistas) foram analisadas de acordo com os princípios de codificação da Ground Theory (codificação, aberta, axial e seletiva) (Glaser e Strauss, 1999). Assim, separadamente, foi efetuada uma leitura cuidada dos elementos presentes nas timelines e das transcrições, para de seguida se proceder à codificação aberta tendo em conta o propósito do estudo. Da codificação aberta passou-se à fase de comparação, contrastação e agregação, realizada entre os elementos de equipa de investigação, na procura de identificar padrões condutores da definição dos grandes temas. Da análise das timelines emergiram três temas:

1. envolvimento afetivo;

2. confronto situacional; e

3. aquisições.

$\mathrm{E}$ dos dados das entrevistas surgiu mais um tema: interações com outros e com o meio (Quadro 1).

Quadro 1 - Temas emergentes da análise de dados.

\begin{tabular}{|l|l|}
\hline $\begin{array}{l}\text { Envolvimento } \\
\text { afetivo }\end{array}$ & $\begin{array}{l}\text { Emoções veiculadas pelos estudantes-estagiários, que de alguma forma geraram } \\
\text { conflito em suas estruturas mentais e mudanças no decurso do estágio. }\end{array}$ \\
\hline $\begin{array}{l}\text { Confronto } \\
\text { situacional }\end{array}$ & $\begin{array}{l}\text { Conflitos gerados pelas dificuldades que os estudantes-estagiários } \\
\text { identificaram em resultado do confronto com as tarefas e exigências da } \\
\text { profissão docente. }\end{array}$ \\
\hline Aquisições & $\begin{array}{l}\text { Conhecimentos e competências referenciadas pelos estudantes-estagiários } \\
\text { como adquiridas no processo de estágio. }\end{array}$ \\
\hline $\begin{array}{l}\text { Interações com } \\
\text { outros e com 0 } \\
\text { meio }\end{array}$ & $\begin{array}{l}\text { Momentos de contato dos estudantes-estudantes com outros agentes } \\
\text { (elementos do núcleo de estágio, alunos e professores do grupo de educação } \\
\text { física) ou com o contexto sociocultural da escola, na qual emergiram reações } \\
\text { significativas. }\end{array}$ \\
\hline
\end{tabular}

Fonte: Banco de dados da pesquisa.

Elaboração das autoras. 
Em articulação com a análise efetuada, os resultados foram organizados em duas componentes: na primeira foram reportadas as experiências decorrentes dos padrões globais da análise das timelines de todos os estudantes-estagiários, pontuando a identificação das semelhanças e dissemelhanças; e na segunda foram apresentados os perfis individuais de três estudantes-estagiários que se destacaram pelas tipologias diferenciadas que evidenciaram.

De referir que na representação gráfica dos resultados oriundos das $t i-$ melines, a temática envolvimento afetivo (positivo e negativo) está representada com o sinal (__ $)$ e o confronto situacional (dificuldades) e aquisições com o sinal (------). Dos resultados provenientes das entrevistas, a identificação dos excertos foi efetuada com o nome fictício do participante, a sigla "ref." e respetivo número.

\section{RESULTADOS}

\section{DO PERFIL GLOBAL AOS PERFIS INDIVIDUAIS DOS ESTUDANTES-ESTAGIÁRIOS}

Um primeiro dado que emergiu da análise das timelines construídas pelos estudantes-estagiários foi a existência de um confronto situacional (materializado nas dificuldades sentidas na prática), o que promoveu emoções predominantemente negativas. Em uma fase inicial (setembro/outubro), os estudantes-estagiários mencionaram como dificuldades o trabalho em núcleo de estágio e as tarefas de preparação e realização do processo de ensino-aprendizagem, nomeadamente a avaliação diagnóstica, a seleção de tarefas de aprendizagem, a gestão e o controlo da disciplina dos alunos da turma. Já em uma fase posterior (novembro), os estudantes-estagiários destacaram o volume de trabalho e a necessidade de tomarem decisões, evidenciando cansaço e desmotivação. Nesse período marcado por um envolvimento afetivo negativo, dois estudantes-estagiários refletiram também sobre seu papel e desempenho como professores, sentindo dúvidas relativamente à sua identidade como docentes.

Não obstante esse padrão predominante, os estudantes-estagiários destacaram aquisições ao nível da intervenção pedagógica, que, se para alguns estudantes-estagiários não foram suficientes para superarem as emoções negativas, noutros geraram um envolvimento afetivo bastante positivo, porquanto sentiram confiança, motivação e satisfação no desempenho de suas funções.

Um envolvimento afetivo positivo foi igualmente evidenciado por alguns estudantes-estagiários logo na fase inicial do estágio profissional (setembro/outubro), marcado pelo entusiasmo e motivação, em resultado da descoberta da cultura profissional, das interações positivas com a comunidade escolar e da realização das primeiras tarefas relacionadas com a preparação do ensino. Esses estudantes-estagiários valorizaram a oportunidade de "viver a escola" como professores, partilhando os espaços e conhecimentos de um grupo profissional. Na perspetiva dos estudantes-estagiários, foi por meio desse processo de integração e interação com o contexto e com os outros que foram descobrindo o papel do professor na escola e o verdadeiro sentido do ensino da educação física. 
Outro dado que emergiu do perfil global das experiências emocionais experienciadas pelos estudantes-estagiários revela que o envolvimento afetivo negativo é maioritariamente desencadeado pelas dificuldades geradas pelo confronto situacional, sendo este o principal mecanismo para novas aprendizagens. Já as aquisições são, geralmente, associadas ao envolvimento afetivo positivo e adquiridas fundamentalmente pelas interações estabelecidas pelos estudantes-estagiários com o contexto e outros agentes.

Não obstante as similitudes identificadas nas experiências emocionais evidenciadas pelos estudantes-estagiários, a análise de cada caso em particular colocou em evidência que o desenvolvimento desses sujeitos é um processo distinto, individualizado e não linear. De entre os participantes no estudo, diante de suas particularidades, foram selecionados três casos para aprofundamento e apresentação: Maria, cujo percurso foi marcado pela desilusão, decorrente principalmente de um confronto situacional negativo; Sissa, com um percurso inconstante, mas de acentuado desenvolvimento; $\mathrm{e}$ Índia, com um percurso marcado por um constante estado de sobrevivência.

\section{Maria - aprender a partir do confronto situacional no contexto de estágio}

Maria, não obstante as dúvidas que evidenciava no início do estágio profissional acerca do que iria encontrar, depressa as superou, dando lugar a um envolvimento afetivo positivo, marcado pela satisfação (Figura 2).

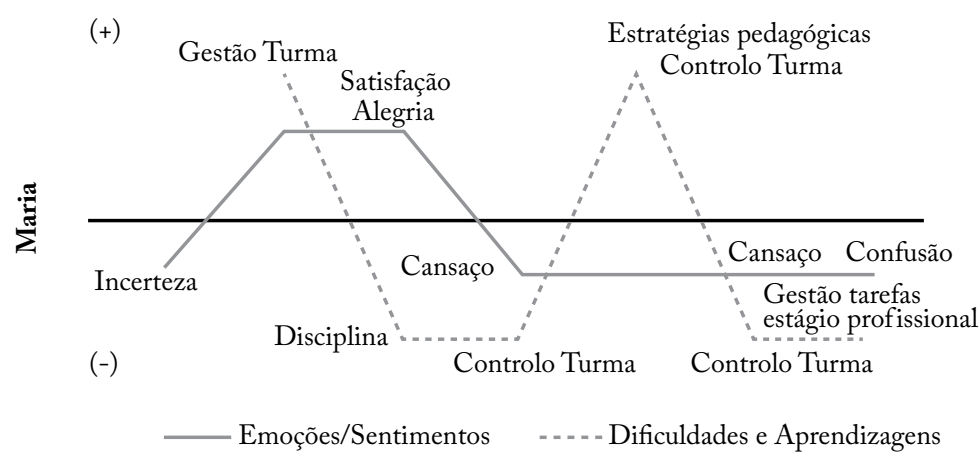

Figura 2 - Timeline de Maria: emoções positivas e negativas, aquisições e dificuldades. Fonte: Elaboração das autoras.

Nessa fase inicial do EP, Maria valorizava muito o contacto com os alunos na escola, embora fosse nesse contexto que enfrentava os primeiros desafios do processo de ensino-aprendizagem, nomeadamente os relacionados com a gestão e organização da turma. Diante desse confronto situacional, de resolução complexa, a estudante admitiu a importância de planear e organizar de forma adequada o processo de ensino-aprendizagem dos alunos (Maria: ref. 10), reconhecendo as dificuldades na realização dessa tarefa, principalmente nas modalidades em que tinha menor domínio da matéria de ensino. 
São poucas as pessoas que têm noção do difícil que é planear uma aula de EF, porque não é só dizer vou fazer este exercício. Além de escolher os exercícios, temos que definir os objetivos que queremos. Primeiro temos objetivos para a aula e depois, em função dos objetivos, escolhemos os exercícios e depois temos que perceber qual é a melhor forma de organização da turma, das tarefas e fazer a gestão do material e do tempo [...] é stressante e esgotante. (Maria: ref. 10)

Não obstante essa atitude positiva perante os desafios, ao longo dessa primeira etapa de estágio profissional, os conflitos provenientes de uma turma problemática e o volume de trabalho inerente ao processo de ensinar (planear, atuar e gerir, refletir e ajustar) conduziram Maria a um estado de cansaço constante, que por sua vez, fez emergir um sentimento de desinteresse e insatisfação. Embora a estagiária conseguisse resolver alguns dos problemas relacionados com o controlo da turma e adquirir ferramentas ao nível das estratégias pedagógicas, as dificuldades nesse âmbito tenderam a persistir. Com efeito, foi nessa busca constante de soluções para os problemas que Maria percebeu a necessidade de reajustar o planeamento ao contexto, às caraterísticas da turma e às especificidades das modalidades lecionadas:

Nas estratégias para controlo da turma, percebi que nunca posso ou nunca podia ter uma estratégia definida como uma rotina [...]. Tinha que variar sempre, tanto era sentá-los para explicar o exercício, como ir para o quadro e fazer desenhos [...] Percebi que nunca podia ser o mesmo, tinha sempre que variar se numa modalidade estava a fazer de determinada forma, na outra tinha que encontrar uma forma mais eficaz de transmitir as coisas. (Maria: ref. 18)

Já no final desse primeiro período letivo, além do controlo da turma, Maria apontou dificuldades ao nível da gestão do tempo de aula, que foram sendo superadas pela reflexão acerca da prática, o que gradualmente possibilitou a reconstrução de entendimentos acerca do processo de ensino-aprendizagem:

[...] comecei a perceber que se calhar colocava demasiadas tarefas para as aulas [...] muitas vezes falava com a minha professora cooperante e ela dizia "está atenta ao tempo porque não estás a conseguir cumprir com a aula que planeias", e eu dizia, "se calhar a estratégia não é estar atenta ao tempo, é retirar tarefas à aula e não o tempo às tarefas". (Maria: ref. 14)

Nessa fase, Maria também destacou a desorientação que sentiu aquando da realização de uma das atividades da escola (corrida do Pai Natal), na medida em que não lhe foi conferida autonomia para atuar na melhoraria de aspetos organizativos que considerava essenciais:

[...] esta tal confusão, prende-se com a primeira atividade que tivemos de organizar. A corrida do Pai Natal [...] se calhar por não termos autonomia que estava à espera de ter e como estávamos muito dependentes dos professores, foi um bocado confuso, porque no ano passado foi assim e tinha de ser assim, e havia coisas que não tinham ficado muito claras para nós [...]. (Maria: ref. 15) 
Embora a timeline de Maria revele um envolvimento afetivo maioritariamente negativo (após outubro), então decorrente dos conflitos gerados pelas exigências situacionais, a estudante-estagiária reconheceu que foram as constantes dificuldades que lhe permitiram consciencializar-se de suas fraquezas e necessidades e, simultaneamente, a estimularam na procura de soluções para os problemas que surgiam.

O facto de sentir mais dificuldade... nada disso me desmotivou, aliás isso foi das coisas que também contribuiu para eu querer e saber que tinha de fazer mais pesquisa, procurar alternativas, mais soluções, e deu para perceber que é isto que gosto de fazer [...] só me ajudaram a perceber onde é que estavam as minhas fragilidades e aquilo em que precisava de apostar mais e melhorar. (Maria: ref. 5)

Não obstante as experiências emocionais positivas terem sido as que mais motivaram Maria para o estágio profissional, ela reconheceu que os momentos de dificuldade foram os que mais a impulsionaram a aprender.

\section{Sissa - aprender pela participação e negociação}

O percurso da Sissa foi claramente marcado por altos e baixos (Figura 3), sendo que a componente relacionada com o processo de ensino-aprendizagem foi a que mais contribuiu para esse estado emocional.

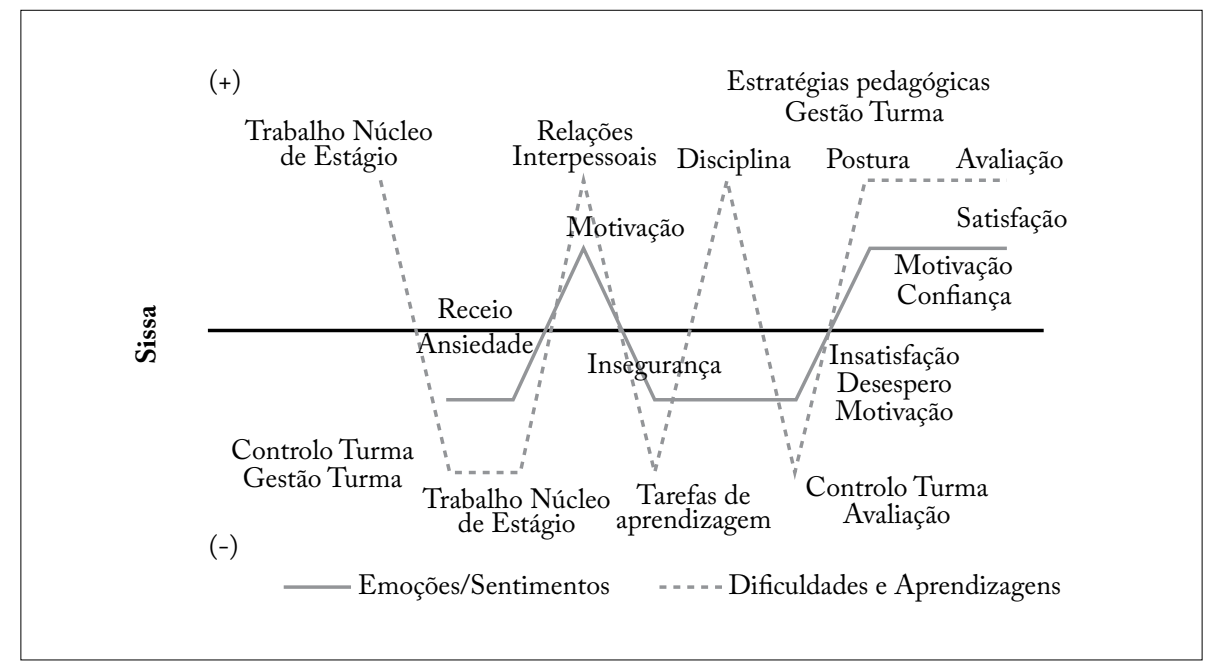

Figura 3 - Timeline de Sissa: emoções positivas e negativas, aquisições e dificuldades.

Fonte: Elaboração das autoras.

Inicialmente, Sissa revelava receio pelo desconhecido, que foi sendo superado pelo apoio emocional que encontrou nos colegas de núcleo de estágio desde o primeiro contacto com o estágio profissional. $\mathrm{Na}$ fase inicial, Sissa considerou as discussões com o núcleo de estágio e a partilha de experiências fundamentais para superar seus receios e dificuldades, particularmente ao nível do controlo e gestão 
da turma. Sissa valorizava não só a interação social com os colegas de estágio como com o contexto, conforme espelha seu discurso:

[...] porque foi através das nossas discussões e da nossa união que conseguimos ultrapassar alguns destes receios e partilhar experiências [...] falávamos muito sobre este primeiro contato com os alunos [...] porque era uma fase em que ainda nos estávamos a dar a conhecer, não sabíamos se havíamos de ser mais exigentes, se deveríamos de ser mais flexíveis. Ajudamo-nos através dessa partilha de experiências e percebemos que foi um bocadinho diferente entre todos, o que veio corroborar com aquela ideia de que tudo depende do contexto. (Sissa: ref. 3)

Embora a interação com os colegas de estágio fosse interpretada como benéfica à sua aprendizagem, Sissa também identificou alguns conflitos no seio do grupo. No entanto, foram esses conflitos relacionais que desencadearam novas aquisições, em resultado do processo de negociação de entendimentos e significados, que então lhe permitiam aprender a lidar com as pessoas que possuíam objetivos distintos e defendiam perspetivas diferentes:

[...] apesar de ter sido muito importante, houve também problemas entre [os elementos do] grupo, na forma como lidávamos uns com os outros. Éramos todos muito diferentes e tínhamos vidas diferentes [...] Acho que era um pouco a questão dos objetivos, não sei se teríamos todos os mesmos objetivos e era um bocadinho difícil. Nesta fase inicial que era tão importante o trabalho de grupo, nem todos tinham esse interesse. Havia pessoas mais individualistas e outras que queriam realmente partilhar. (Sissa: ref 6)

O contacto com a prática pedagógica, perante as dificuldades sentidas, foi marcado pela insegurança e alguns momentos de insatisfação e desmotivação. Contudo, esses momentos também foram marcados pela autorregulação de Sissa, que na busca de soluções, conseguiu adquirir aprendizagens ao nível da intervenção pedagógica e construir, pela prática e reflexão, o seu próprio conhecimento:

[...] eu senti que não me podia guiar apenas pelas estratégias que conhecia ou que existiam na teoria, só na prática é que sentia se uma estratégia que tinha definido anteriormente funcionava na aula, então aprendi que alterar estas estratégias não tinha problema nenhum, antes, pelo contrário, só no momento é que eu saberia aquilo que deveria aplicar. (Sissa: ref. 9)

Outra dificuldade apontada por Sissa centrou-se nos condicionalismos sentidos pelas diretrizes do grupo de educação física, uma vez que, por vezes, não tinha espaço para tomar decisões e colocar em prática algumas ideias que defendia:

Mais dificuldades na avaliação e também um bocado no ensinar, devido aos condicionalismos da própria escola [...] o facto de ter de lecionar de determinada forma ou abordar determinadas modalidades, foi mais difícil porque ia um bocadinho contra aquilo em que acreditava [...]. (Sissa: ref. 16) 
Nesse quadro experiencial, foram os sucessos e insucessos que originaram a trajetória irregular do processo de aprendizagem de Sissa, sendo os momentos de superação os que mais a estimulavam a aprender. Não obstante, Sissa também reconhece a importância dos momentos difíceis em seu processo de aprendizagem, uma vez que a levaram a refletir sobre suas práticas:

Os sucessos deram-me confiança e fizeram-me acreditar ainda mais naquilo que fazia, nas minhas decisões. Os insucessos foram momentos que se calhar deitavam-me um bocadinho abaixo [...] mas passado uns dias, com a reflexão, via tudo de outra forma. (Sissa: ref. 8)

\section{Índia - aprender sobrevivendo e descobrindo uma nova identidade}

O percurso de Índia foi marcado por um constante estado de sobrevivência (Figura 4), em virtude das dificuldades de estabelecer uma relação positiva com os alunos da turma.

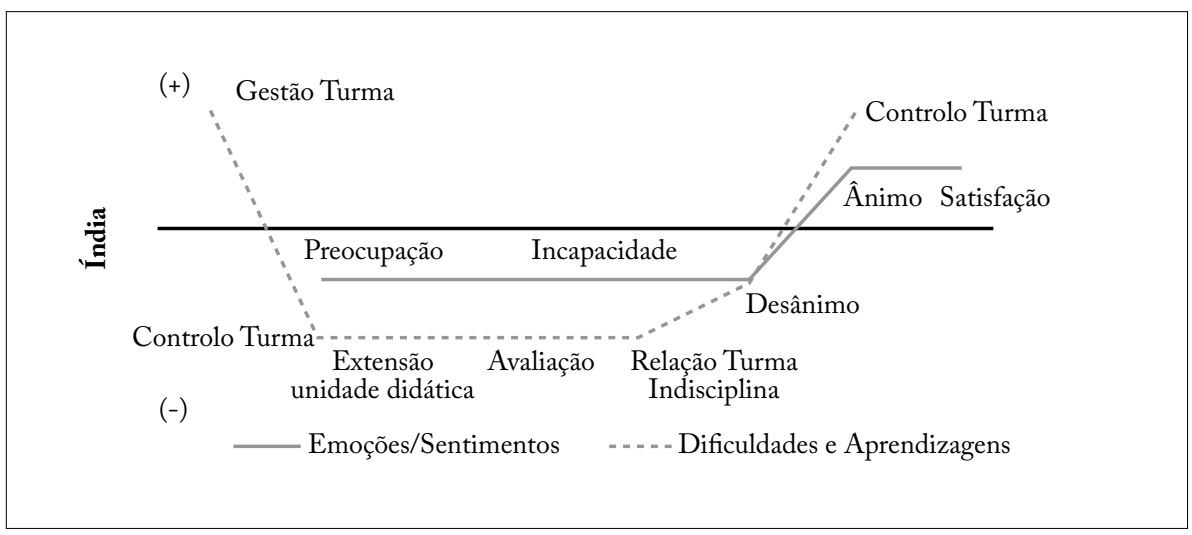

Figura 4 - Timeline de Índia: emoções positivas e negativas, aquisições e dificuldades. Fonte: Elaboração das autoras.

O primeiro contato de Índia com a turma foi referenciado como um momento positivo, que a sensibilizou. Contudo, ao longo do primeiro período letivo, os constantes conflitos gerados pelas tarefas inerentes ao processo de ensino-aprendizagem dos alunos (e.g., avaliação diagnóstica, o planeamento das unidades didáticas e o controlo da turma), originaram sentimentos negativos, como a preocupação, a incapacidade e a desmotivação:

[...] eu sentia bastante frustração, porque sentia que não conseguia aderir da mesma forma a todos os alunos ou pelo menos estar com todos. (Índia: ref. 1)

[...] tinha dificuldades em lidar com a indisciplina e em mostrar aos meus alunos que gostava deles. Tinha dificuldade em muita coisa que ao longo do ano admito que não consegui ultrapassar. (Índia: ref. 9) 
No decurso desse período, Índia revelou essencialmente problemas no controlo da turma e na tomada de decisões durante as aulas:

[...] a aula até podia estar bem organizada, mas com o decorrer da aula, o ter os alunos perto de mim e se eles fizessem alguma asneira eu ficava desmotivada e já não conseguia pensar com a mesma clareza, e já não conseguia improvisar (reajustar) da mesma forma. (Índia: ref. 2)

Diante da instabilidade emocional patente, Índia também evidenciou dificuldades em ajustar sua identidade pessoal às exigências do contexto profissional, particularmente de reajustar a sua postura enquanto professora aos comportamentos inadequados dos alunos, vivenciando alguns conflitos nessa passagem de estudante para professora. Essa carga emocional negativa colocou em causa a sua confiança e até mesmo a continuidade no estágio profissional. Apesar desse estado emocional negativo, os poucos momentos positivos que ia vivenciando davam-lhe alento e incentivo para continuar o processo formativo:

[...] houve coisas que não consegui superar porque não consegui superar o estado emocional de desmotivação e de tristeza [...] Enquanto professora, estas dificuldades puseram muito em causa a minha confiança em querer seguir esta área. Os [momentos] mal-sucedidos colocaram isso bastante em causa. Eu sentia que a minha maneira de ser [pessoal] não era compatível com a minha profissão, a minha maneira de ser professora. Os [momentos] bem-sucedidos fizeram-me nunca desistir de perceber que realmente é este o meu caminho e que formar pessoas, muito mais do que formar alunos, é realmente aquilo para o qual eu nasci. Os positivos superaram sempre os menos positivos, e foi esse o principal estímulo para continuar e não desistir. (Índia: ref. 5)

No que concerne a outras tarefas regulamentadas pelas normas de estágio profissional, Índia valorizava as aulas observadas aos colegas do núcleo de estágio, porquanto estimulavam a ação reflexiva, tanto no coletivo como no individual, favorecendo o seu processo de aprendizagem. Índia reconheceu, assim, que a partilha de experiências foi fundamental para aceder a outras formas de pensar e de atuar. Nesses espaços de partilha e de reflexão em grupo, a estudante percebeu que conhecimento e comportamentos precisam de ser ajustados ao contexto:

[...] ao observar as aulas dos meus colegas, eu senti que os métodos dos meus colegas também funcionavam, mas depois percebi que, ao longo do estágio, a maior parte das coisas que os meus colegas aplicavam nas turmas deles não se aplicavam na minha. (Índia: ref. 4)

Não obstante a carga emocional negativa que acompanhou Índia e que condicionou seu desenvolvimento como professora, ela revelou uma ligeira satisfação (ver timeline - Figura 4) no final do primeiro período letivo, em resultado de percecionar uma melhoria na relação com os alunos da turma. 
O constante envolvimento afetivo negativo que Índia vivenciou ao longo da primeira etapa do estágio não lhe permitiu superar algumas dificuldades, designadamente o controlo da turma, que de certo modo condicionou sua aprendizagem, colocando em causa a configuração de sua identidade como professora.

\section{DISCUSSÃO}

Os dados revelam que a construção e a reconstrução do conhecimento dos estudantes-estagiários é um processo desencadeado a partir dos problemas emergentes do contexto, principalmente os relacionados com o processo de ensino-aprendizagem dos alunos, sendo o envolvimento emocional e a interação com o meio e com os outros os principais reguladores do processo de aprendizagem dos estudantes-estagiários. Essas evidências reforçam a ideia de que o processo de aquisição (aprendizagem) implica necessariamente a relação entre as dimensões cognitiva, emocional e social (Alves et al., 2018), que caraterizam um processo de transformação do estudante como um todo (Illeris, 2014), sendo os momentos de crise causados pelos desafios experienciados na relação com os outros e o meio (Vygotsky, 1978), importantes para o despoletar dessas mudanças.

Os momentos irregulares ou de crise, presentes nas linhas do tempo dos estudantes-estagiários, emergiram como sendo aqueles que os levaram a refletir sobre suas práticas e sobre si mesmos, sendo, por isso, momentos cruciais para o processo de aprendizagem. Não obstante os estudantes-estagiários entenderem os momentos positivos como o principal motor para aprenderem, porquanto lhes conferiam confiança e motivação para um maior envolvimento em seu processo de aprendizagem, reforçando até mesmo a vontade de serem professores, também admitiram que foram os momentos de dificuldade que lhes permitiram reconhecer suas fragilidades e entender que precisavam de (re)construir entendimentos e investir mais em sua formação. Nesse contexto, foram as experiências negativas que conduziram a uma constante reflexão sobre as próprias crenças e representações, obrigando-os a repensarem suas práticas e a negociar novos significados (Lave e Wenger, 1991; Wenger, 1998), tanto com o meio (experimentação) como com os outros (partilha). A noção de que aprender a ser professor não é um processo de crescimento constante, mas um processo irregular (com altos e baixos), caraterizado por alguns períodos de mudança, ficou bem patente. De facto, conforme Moir $(1999)^{5}$ veicula, percebe-se pelo modo como os estudantes-estagiários expõem suas vivências de estágio, que o seu processo de aprendizagem foi marcado inicialmente por um período de antecipação, seguido de um período de sobrevivência e de desilusão, sendo que alguns participantes conseguiram alcançar um período de rejuvenescimento e reflexão.

No presente estudo, a entrada no estágio profissional surge como uma etapa marcante na vida dos estudantes-estagiários, que, se para alguns foi uma etapa

5 Tradução das autoras de: antecipation; survival; desillusionnment; rejuvenation; reflection (Moir, 1999, p. 19-23). 
encarada com entusiasmo, para outros foi uma etapa marcada pelo "choque com a realidade" (Hüberman, 2000; Veenman, 1984), com um envolvimento afetivo predominantemente negativo (insegurança e preocupação). Esse confronto resultou das diferenças encontradas entre as expetativas e a realidade, sobre a complexidade do ensino e a incerteza de conseguir atingir metas exigentes (Timoštšuk e Ugaste, 2010). No mesmo sentido, estudos recentes (Alves et al., 2018; Anttila et al., 2017) destacam esse confronto com a realidade acrescentando às expectativas irrealistas as habilidades que estimavam ter, reforçando, assim, a necessidade de a formação de professores assegurar uma melhor preparação dos estudantes para essa realidade. Hüberman (2000) refere que a entrada na profissão nem sempre é vivida de modo positivo pelos professores principiantes, identificando dois estádios nessa fase de adaptação, também evidenciados nos resultados deste estudo: o da sobrevivência, representado pelo confronto inicial com a complexidade da situação profissional e caracterizado pelo tatear constante e pela preocupação consigo próprio (Queirós, 2014); e o da descoberta, resultante do entusiasmo inicial, da experimentação e da vontade de ser professor. Esse confronto situacional (choque com a realidade) gera emoções que interferem positiva ou negativamente nas capacidades cognitivas e comportamentais dos estudantes-estagiários. Por exemplo, emoções como ansiedade, receio, incapacidade e insegurança podem reduzir os recursos cognitivos disponíveis para refletir e agir; e, em contraponto, emoções como motivação e satisfação podem aumentar o foco na tarefa em mãos, permitindo a plena utilização dos recursos cognitivos e induzindo um forte ânimo para lidar com os eventos negativos (Pekrun et al., 2007). Com efeito, como explicam Pekrun et al. (2007), as emoções positivas, como a satisfação, aumentam a autorregulação, enquanto as emoções negativas, como a ansiedade, apelam a uma dependência da orientação externa.

Não obstante esse padrão, as emoções negativas, como a ansiedade, habitualmente advindas do baixo controlo e do desconhecimento das tarefas inerentes ao papel de docente, quando acompanhadas de emoções positivas e de apoio constante e imediato, podem potenciar a construção de uma boa base para a aprendizagem. Nesse processo, os professores orientadores assumem um papel preponderante, nomeadamente no apoio e na regulação das emoções dos estudantes-estagiários, fomentando o alcance de metas de aprendizagem realistas e estimulando nos estudantes uma atitude preventiva e reflexiva (Timošyšuk, Kikas e Normak, 2016). Desse modo, conhecer bem os estudantes-estagiários e mediar suas expetativas no momento de entrada no estágio profissional é um elemento fundamental para que o estágio profissional seja um momento catalisador do processo de aprendizagem, e não um obstáculo ao desenvolvimento do estudante-estagiário. Uma atitude de apoio emocional dos orientadores e de apoio pedagógico específico emerge, assim, como recurso importante para que o estudante-estagiário reverta os momentos de dificuldade em momentos de aprendizagem (Anttila et al., 2017).

Embora semelhantes, os percursos dos estudantes-estagiários distinguiram-se pelo modo particular como cada um agiu, reagiu e interagiu com o meio e com os outros, aquando do confronto com o contexto real de ensino e das tarefas específicas inerentes ao papel de professor. A natureza biográfica e pessoal do processo de aprendizagem ficou assim evidente (Dubar, 1997), porque, embora a aprendizagem 
tenha acontecido no coletivo (na interação com os outros - alunos, colegas de estágio, outros professores), ocorreu de forma distinta em cada estudante-estagiário, em resultado da interpretação e reinterpretação das experiências vividas por cada um e da capacidade de produzirem respostas em desenvolvimento de novas estruturas (Goel et al., 2010), de modo que pudessem superar as dificuldades com que se foram deparando.

Maria, não obstante apresentar um percurso marcado pelo desânimo e cansaço, foi mencionando algumas aquisições advindas da experimentação e da reflexão que lhe permitiram solucionar temporariamente os problemas da prática. A estudante-estagiária sentia dificuldade em efetuar uma análise profunda das situações vivenciadas na prática, que não lhe permitiam aceder a funções psicológicas superiores — acomodação (Piaget, 1977). Ou seja, Maria não se mostrou capaz de adequar os elementos culturais assimilados ao contexto de sua prática. De facto, ao descrever seus pequenos sucessos ou fracassos, a estudante-estagiária raramente fez uma autoanálise profunda dos acontecimentos, limitando-se a descrever os acontecimentos vivenciados - o que fazia e como se sentia. A ausência de fundamentação concetual na interpretação das dificuldades e na tomada de decisões (Timoštšuk e Ugaste, 2010) marcou seu processo de estágio, e apenas na fase final dessa etapa formativa (dezembro) ela conseguiu alcançar esse nível de entendimento. Mais uma vez, os orientadores emergem com um papel fundamental na mediação desse processo de análise e reflexão, ajustando seu apoio às necessidades de cada estudante-estagiário (Gomes, Queirós e Batista, 2014) na procura de atuar na ZDP de cada um (Vygotsky, 1978, 1998). Como evidenciado nas dificuldades dos estudantes-estagiários, importa que os orientadores deem especial atenção e apoio ao planeamento e à reflexão, privilegiando processos de aprendizagem ativos — questionamento, partilha e negociação —, pois, como refere Wenger (1998), a aprendizagem é antes de tudo a capacidade de negociar novos significados. Nesse processo reflexivo, os estudantes-estagiários precisam de se (re)posicionar em relação ao contexto e aos outros, mas também em relação às conceções teóricas (Meijer, Graaf e Meirink, 2011), conseguindo ir além da acumulação de experiências. Importa, assim, que os estudantes-estagiários encontrem justificações e significados para as diferentes situações vivenciadas, para que possam ocorrer melhorias em suas práticas e interiorização de novos entendimentos. Por essa razão, na formação de professores importa formar os estudantes no sentido de se tornarem capazes de assumir o controlo da própria aprendizagem, por meio da definição de metas de aprendizagem e na monitorização do seu progresso (reflexão).

O percurso de Sissa, à semelhança de Maria, também não foi linear, sendo marcado por frequentes oscilações entre emoções positivas e negativas. Para Sissa, a relação com o contexto e com os outros (alunos, núcleo de estágio e grupo de educação física) foi um mecanismo fundamental para despoletar aprendizagens, quando criados espaços para a reflexão, partilha e negociação. Inicialmente, a aprendizagem vivenciada em núcleo de estágio foi muito valorizada por Sissa, porquanto considerava a partilha de experiências fundamentais para superar seus receios e dificuldades relacionados com a prática pedagógica. Mas com o tempo, embora continuasse a reconhecer a importância desse contexto social para o seu processo 
de aprendizagem, ficaram evidentes algumas dificuldades de gerir os conflitos gerados no grupo, principalmente em virtude dos interesses e da participação de cada um, bem como das interações estabelecidas entre si. Como afirmam Wenger, McDermott e Snyder (2002, p. 55),

As pessoas participam em comunidades por diferentes razões - algumas porque a comunidade traz um valor direto acrescido, outras pelas relações pessoais e outras pela oportunidade de melhorar as suas capacidades. Costumamos pensar que todos os membros da comunidade devem ser encorajados a participar de forma igualitária, mas, como as pessoas têm diferentes níveis de interesse na comunidade, essa expectativa é irrealista.

São alguns desses fatores que de certo modo afetam o processo de aprender em contexto de interação, pois, se por um lado as exigências colocadas ao grupo ensinam cada elemento a viver em comunidade, negociando formas de trabalho, entendimentos e significados, por outro podem reduzir os efeitos positivos desse contexto social, que, perdendo a intencionalidade de se ajudarem, tornam-se comunidades meramente institucionalizadas. Importa, portanto, que um núcleo de estágio funcione como um grupo de afinidade, em que os elementos estão dispostos a participar em práticas específicas, que fornecem a cada um dos seus membros as experiências necessárias ao seu desenvolvimento pessoal e profissional e que, em conjunto, promovam o desenvolvimento do próprio grupo (Wenger, 1998).

Sissa referiu ainda como dificuldade os condicionalismos na prática pedagógica instigados pelas diretrizes do grupo de educação física (estrutura), ${ }^{6}$ uma vez que limitavam algumas de suas decisões e não lhe permitiam testar suas conceções sobre o modo de ensinar e avaliar. Essa necessidade de agência ${ }^{7}$ de Sissa acentuava-se à medida que se tornava mais autónoma, confiante e capaz de considerar a teoria e a razão em suas práticas, assumindo uma participação cada vez mais ativa no próprio processo de aprendizagem. De facto, nesse contexto real de ensino, a aprendizagem é favorecida pela participação plena dos estudantes-estagiários, o que envolve não apenas compromisso, tempo, esforço e realização de tarefas, mas principalmente um trabalho cada vez mais autónomo e reflexivo, que lhes permitam uma renegociação situada de significados (Cardoso, Batista e Graça, 2014). Ao encontrarem equilíbrio com a entrada no sistema da escola e perceberem a necessidade de cultivar suas agências, os estudantes-estagiários conquistam maior confiança em suas capacidades para serem professores, adquirindo novas oportunidades de aprendizagem (Alves $e t$ al., 2018; Anttila et al., 2017), em um processo de acomodação no qual os conhecimentos e comportamentos mentais sofrem mudanças e reajustes em suas estruturas (Piaget, 1977), conforme a circunstância e o significado atribuído pelo sujeito.

6 Estrutura refere-se às regras e recursos, que parecem influenciar ou limitar as escolhas e oportunidades individuais de cada (MacPhail e Tannehill, 2012, p. 300).

7 Agência refere-se à capacidade de os indivíduos agirem de forma independente e de realizarem livremente as suas próprias escolhas (MacPhail e Tannehill, 2012, p. 300). 
Nessa sequência de ideias, na interação com o contexto, Sissa destacou a importância de repensar suas preconceções, construídas durante a socialização antecipatória, no intuito de reajustá-las, reconstruindo, se necessário, novos entendimentos acerca do processo de ensino.

As experiências positivas, associadas aos momentos de aquisição, também marcaram o percurso de Sissa, tendo surgido, frequentemente, após momentos de desmotivação e insatisfação. Esses períodos sinalizavam o início de um período de crescimento, em que Sissa tomava um controlo ativo sobre o seu processo de aprendizagem. Tal remete para a noção de que a aprendizagem ocorre por um processo de transformação, caraterizado por mudanças no autoconhecimento do estudante, que lhe fornece novas compreensões e padrões de ação (Illeris, 2002). Esse processo, designado de "transformative learning" é reconhecido por Mezirow (2000) como um modo mais profundo de aprender sobre si mesmo e sobre sua atitude em relação à vida (nesse caso em relação às suas práticas profissionais), causando mudanças na autoperceção e na identidade do sujeito. Segundo Illeris (2002), esses momentos de transformação tendem a ocorrer em situação de crise e envolvem a reestruturação simultânea dos esquemas cognitivos e emocionais. $\mathrm{Na}$ formação de professores, a existência dessa transformação requer ferramentas psicológicas (Gomes, Queirós e Batista, 2014) que estimulem o desenvolvimento dos estudantes-estagiários, nomeadamente a reflexão, que, como evidenciaram Maria e Sissa, surge como fundamental para a aprendizagem enquanto atividade metacognitiva (Bransford, 1999).

Por último, Índia evidenciou um percurso predominantemente negativo, pautado por um estado de sobrevivência constante, em virtude da contínua dificuldade em suprir as exigências do contexto (e.g., avaliação, planeamento, controlo da turma, disciplina). Como advogam vários autores (Meijer, Graaf e Meirink, 2011; Timoštšuk, Kikas e Normak, 2016; Timoštšuk e Ugaste, 2010), são esses momentos que originam nos estudantes-estagiários sentimentos como desmotivação ou desilusão. Geijsel e Meijers (2005) referem que esses períodos são importantes para os processos de aprendizagem de uma identidade e que essas experiências de fronteira acontecem quando uma pessoa, ao participar plenamente de uma prática social, encontra uma situação na qual se sente incapaz de dar resposta porque não se identifica com a nova situação ou com as suas exigências. Segundo esses mesmos autores, os indivíduos que entram nessa insegurança existencial não estão, inicialmente, dispostos a aceitar a situação e a abandonar os laços anteriores de sua identidade, assumidos durante a socialização antecipatória. Esse quadro mostrou-se bastante evidente no percurso de Índia, pela persistência das dificuldades relacionadas com a lecionação das aulas, colocando em causa a sua confiança para seguir a profissão docente, gerando conflitos entre sua identidade pessoal e sua identidade profissional. O estado emocional negativo, predominante no percurso de Índia, fê-la sentir-se incapaz na função de professora, aportando dúvidas acerca de como ensinar ou sobre seu papel como professora. Para restaurar a configuração da identidade e as novas vivência, Índia precisava de estabelecer um equilíbrio entre suas emoções e cognições (Geijsel e Meijers, 2005), pela partilha de conceitos e significados em um ambiente social positivo, no qual encontraria apoio e explicações lógicas com 
sentido pessoal (significados representativos para si), que a motivasse a agir e a mudar de comportamento. Contudo, o estado de desilusão instaurado não permitiu que as experiências de Índia fossem catalisadoras da autorreflexão (Meijer, Graaf e Meirink, 2011). Nesses casos, os orientadores, em particular o professor cooperante, têm um papel importante na regulação emocional dos estudantes-estagiários, por meio da promoção de discussões e de reflexões centradas nas experiências pessoais de cada estudante-estagiário, ajudando-os a lidar com essas fases de desilusão (Meijer, Graaf e Meirink, 2011; Timoštšuk, Kikas e Normak, 2016). Ou seja, diante das experiências negativas, os estudantes precisam de refletir e redefinir novos planos de ação, e aí os agentes da formação assumem um papel importante enquanto mediadores dessa redefinição de planos e de objetivos realistas a curto prazo e ajustados às capacidades individuais, para que então existam sucessos percebidos (Sutton e Wheatley, 2003) e maior envolvimento do estudante no próprio processo de aprendizagem (motivação).

Apesar das dificuldades, Índia reconheceu a importância da partilha e da participação em práticas culturais quotidianas situadas no contexto profissional, as quais lhe permitiram aceder a outras formas de pensar e atuar. Esses dados reforçam a ideia da construção de conhecimento no campo social (dimensão coletiva) para o plano individual (Vygotsky, 1978), evidenciando que parte das transformações pessoais e profissionais que operam em cada indivíduo resulta das interações e práticas estabelecidas nas comunidades que integram, as comunidades de prática (Wenger, 1998).

\section{CONSIDERAÇÕES FINAIS}

As vivências em contexto de estágio dos estudantes-estagiários caracterizaram-se por emoções predominantemente negativas (receio e dúvida), que se acentuaram durante a primeira etapa do estágio profissional (preocupação, incapacidade e insegurança) em virtude das dificuldades geradas no confronto situacional. Não obstante esse envolvimento afetivo negativo, também emergiram emoções positivas (confiança, motivação e satisfação), em resultado das aquisições, embora para alguns participantes as aquisições não fossem suficientes para superarem o estado emocional negativo. Em uma fase inicial, o processo de estágio foi marcado pelo confronto com o contexto, o "choque com a realidade"(Hüberman, 2000; Veenman, 1984), proveniente do desconhecimento da escola, das tarefas prescritas e respetivas responsabilidades, do volume de trabalho e das interações com os elementos do núcleo de estágio e com a comunidade escolar. No decorrer do estágio profissional, os momentos de sucesso e insucesso, decorrentes do desempenho das tarefas inerentes à preparação e realização do processo de ensino-aprendizagem dos alunos (e.g., avaliação diagnóstica, gestão, controlo e disciplina da turma e adequação das tarefas de ensino), foram as experiências mais valorizadas pelos estudantes-estagiários. Com efeito, as experiências negativas (momentos irregulares ou de crise), quando acompanhadas de emoções positivas e de apoio no imediato e continuado por parte dos agentes mediadores, emergiram como catalisadoras do processo de aprendizagem, porquanto requeriam dos estudantes-estagiários a reflexão sobre suas práticas e sobre si mesmos, incitando a reconfiguração de entendimentos e 
comportamentos. Já as experiências positivas, por conferirem confiança e motivação aos estudantes-estagiários, promoveram maior envolvimento dos estudantes em seu percurso formativo, favorecendo também o processo de aprendizagem. Na superação das dificuldades, a participação plena dos estudantes-estagiários nas práticas sociais (Lave e Wenger, 1991), proporcionadas pelo contexto de estágio profissional, a relação com o contexto e os outros e o apoio pedagógico específico e emocional dos orientadores emergiram como fatores fundamentais para que a aprendizagem ocorresse (Meijer, Graaf e Meirink, 2011).

A natureza biográfica e pessoal dos estudantes-estagiários ficou também evidente (Dubar, 1997), revelando que a aprendizagem, enquanto processo dinâmico e cíclico de reconfiguração de significados, em constante mudança, resulta tanto de um processo de construção social como da construção de significado individual (Sutton e Wheatley, 2003).

Aprender a ser professor é um processo caraterizado por constantes mudanças (Illeris, 2002), estas advindas do confronto dos estudantes com as dificuldades geradas pelo contexto. Contudo, para que esse confronto resulte em transformações positivas (aquisições), a formação de professores deve proporcionar aos estudantes um ambiente de aprendizagem em que haja espaço para participação, reflexão, partilha e negociação (Alves et al., 2018; Anttila et al., 2017).

Do estudo importa ainda destacar que, do ponto de vista metodológico, a timeline, quando complementada com entrevistas semiestruturadas, é bastante útil para aceder ao contexto espacial e temporal dos momentos considerados significativos por cada estudante-estagiário e ao modo como diferentes fatores estão associados aos momentos de mudança. Relativamente ao processo de orientação, o estudo mostra que o apoio prestado pelo orientador deve ir além do apoio tecnicista e atender aos diferentes perfis dos estudantes-estagiários, considerando seus estados emocionais então decorrentes do vivenciado e da atribuição de significados que cada um dá às suas práticas. O propósito é colaborar no controlo e regulação emocional, em um processo de coconstrução, na procura de transformar as experiências emocionais em elementos catalisadores da aprendizagem.

Os programas de formação de professores devem, em seu todo e não apenas no contexto de estágio, atentar à componente emocional da aprendizagem, dotando os estudantes de ferramentas que lhes permitam gerir as contradições do processo e o confronto com o contexto real de ensino. Do ponto de vista da investigação importa que os estudos incorporem todo o processo de formação inicial em estudos longitudinais, de natureza situada.

\section{REFERÊNCIAS}

ADRIANSEN, H. K. Timeline interviews: a tool for conducting life history research. Qualitative Studies, Denmark,v.3, n.1,p.40-55,2012.https://doi.org/10.7146/qs.v3i1.6272 ALARCÃO, I.; TAVARES, J. Supervisão da prática pedagógica. Uma perspectiva de desenvolvimento e aprendizagem. Coimbra: Livraria Almedina, 2003. 
ALVES, M.; QUEIRÓS, P.; ANN, M.; BATISTA, P. Becoming a physical education teacher during formalised school placement: a rollercoaster of emotions. European Physical Education Review, London, p. 1-17, 2018. https://doi.org/10.1177/1356336X18785333

ANH, D.; MARGINSON, S. Global learning through the lens of Vygotskian sociocultural theory. Critical Studies in Education, United Kingdom, v. 54, n. 2, p. 143-159, 2013. https://doi.org/10.1080/17508487.2012.722557

ANTTILA, H.; PYHÄLTÖ, K.; SOINI, T.; PIETARINEN, J. From anxiety to enthusiasm: emotional patterns among student teachers. European Journal of Teacher Education, United Kingdom, v. 40, n. 4, p. 447-464, 2017. https://doi.org/10.1080/02619768.2017.1349095

BATISTA, P.; QUEIRÓS, P. O estágio profissional enquanto espaço de formação profissional. In: BATISTA, P.; QUEIRÓS, P.; ROLIM, R. (ed.). Olhares sobre o estágio profissional em educação física. Porto: Editora FADEUP, 2013. p. 33-52.

BRANSFORD, J. How people learn: brain, mind, experience, and school. Washington, DC: National Academy Press, 1999.

CARDOSO, I.; BATISTA, P.; GRAÇA, A. Aprender a ser professor em comunidade de prática: um estudo com estudantes estagiários de educação física. In: BATISTA, P.; GRAÇA, A.; QUEIRÓS, P. (ed.). O estágio profissional na (re)construção da identidade profissional em Educação Física. Porto: Editora FADEUP, 2014.p. 241-265. CARDOSO, I.; BATISTA, P.; GRAÇA, A. Narrativas acerca da formação de professores de Educação Física em contexto de prática supervisionada. Sociologia, Revista da Faculdade de Letras da Universidade do Porto, Porto, v. XXXII, p. 125145, 2016. https://doi.org/10.21747/0872-3419/soc32a6

CLARKE, A.; TRIGGS, V.; NIELSEN, W. Cooperating teacher participation in teacher education: a review of the literature. Review of Educational Research, Thousand Oaks, v. 84, n. 2, p. 163-202, 2014. https://doi.org/10.3102/0034654313499618

COLL, C. Construtivismo e educação: a concepção construtivista do ensino e da aprendizagem. In: COLL, C.; MARCHESI, A.; PALACIOS, J. (org.). Desenvolvimento Psicológico e Educação. 2. ed. Porto Alegre: Artes Médicas, 2000. p. 107-127.

CORNELISSEN, J. J.; VAN WYK, A. S. Professional socialisation: an influence on professional development and role definition. South African Journal of Higher Education, Centurion, South Africa, v. 21, n. 7, p. 826-841, 2007.

DOWLING, F. "Are PE teacher identities fit for postmodern schools or are they clinging to modernist notions of professionalism?" A case study of Norwegian PE teacher students' emerging professional identities. Sport Education and Society, United Kingdom,v. 16, n. 2, p. 201-222,2011. https://doi.org/10.1080/13573322.2011.540425 DUBAR, C. A socialização: construção das identidades sociais e profissionais. Porto: Porto Editora, 1997.

FOSNOT, C. Construtivismo: uma teoria psicológica da aprendizagem. In: FOSNOT, C. (org.). Construtivismo: teorias, perspectivas e prática pedagógica. Tradução S. Costa. Porto Alegre: Artes Médicas, 1998. p. 25-50. 
FRANKS, D. Sociology of emotions. In: SMELSER, N.; BALTES, P. (ed.). International encyclopediaof the social and behavioral sciences. Amsterdam: Elsevier, 2001. p. 4.477-4.484.

GEIJSEL, F.; MEIJERS, F. Identity learning: the core process of educational change. Educational Studies, United Kingdom, v. 31, n. 4, p. 419-430, 2005. https://doi.org/10.1080/03055690500237488

GLASER, B.; STRAUSS, A. The discovery of Grounded Theory: strategies for qualitative research. New York: Aldine de Gruyter, 1999.

GOEL, L. et al. Situated learning: conceptualization and measurement. Decision Sciences - Journal of Innovative Education, Manila, Philippines, v. 8, n. 1, p. 215240, 2010. https://doi.org/10.1111/j.1540-4609.2009.00252.x

GOETZ, T. et al. The glass half empty: how emotional exhaustion affects the state-trait discrepancy in self-reports of teaching emotions. PLoS ONE, San Francisco, v. 10, n. 9, p. 1-14, 2015. https://doi.org/10.1371/journal.pone.0137441

GOMES, P.; QUEIRÓS, P.; BATISTA,P. Aprender a ser professor: o papel dos agentes de mediação na formação inicial de professores de educação física. In: BATISTA; P.; GRAÇA, A.; QUEIRÓS, P. (ed.). O estágio profissional na (re)construção da identidade profissional em educação física. Porto: Editora FADEUP, 2014. p. 241-265. HÜBERMAN, M. O ciclo de vida profissional dos professores. In: NÓVOA, A. (ed.). Vida de professores. 2. ed. Porto: Porto Editora, 2000. p. 31-61.

ILLERIS, $\mathrm{K}$. The three dimensions of learning: contemporary learning theory in the tension field between the cognitive, the emotional and the social. Frederiksberg: Roskilde University Press, 2002.

ILLERIS, K. Transformative learning and identity.Journal of Transformative Education, London, v. 12, n. 2, p. 148-163, 2014. https://doi.org/10.1177/1541344614548423

LANGE, J.; LANGE-BURROUGHS-LANGE, S. Learning to be a teacher. London: Sage Publications, 2017.

LAVE, J.; WENGER, E. Situated learning: legitimate peripheral participation. Cambridge: Cambridge University Press, 1991.

LEUNG, P. Autobiographical timeline: a narrative and life approach in understanding meaning-making in cancer patients. Illness, Crisis \& Loss, London, v. 18, n. 2, p. 111127, 2010. https://doi.org/10.2190/IL.18.2.c

MACPHAIL, A. et al. Leading by example: teacher educators' professional learning through communities of practice. Quest, United Kingdom, v. 66, n. 1, p. 39-56, 2014. https://doi.org/10.1080/00336297.2013.826139

MACPHAIL, A.; TANNEHILL, D. Helping pre-service and beginning teachers examine and reframe assumptions about themselves as teachers and change agents: who is going to listen to you anyway? Quest, United Kingdom, v. 64, n. 4, p. 299-312, 2012. https://doi.org/10.1080/00336297.2012.706885

MAYER, J.; SALOVEY, P.; CARUSO, D. Models of emotional intelligence. In: STERNBERG, R. (ed.). Handbook of intelligence. New York: Cambridge University Press, 2000. p. 396-420. 
MEIJER, P.; GRAAF, G.; MEIRINK, J. Key experiences in student teachers' development. Teachers and Teaching, United Kingdom, v. 17, n. 1, p. 115-129, 2011. https://doi.org/10.1080/13540602.2011.538502

MEZIROW, J. Learning as transformation: critical perspectives on a theory in progress. San Francisco, CA: Jossey-Bass, 2000.

MOIR, E. The stages of a teacher's first year. In: SCHERER, M. (ed.). A better beginning: supporting and mentoring new teachers. Alexandria, VA: Association of Supervison and Curriculum Development, 1999. p. 19-23.

NIAS, J. Thinking about feeling. The emotions in teaching. Cambridge Journal of Education, United Kingdom, v. 26, p. 293-306, 1996. https://doi.org/10.1080/0305764960260301

O'SULLIVAN, M.Learning to teach in physical education. In: SIVERMAN, S.; ENNIS, C. (ed.). Student learning in PE. Champaign: Human Kinetics, 2003. p. 275-294.

PEKRUN, R. et al. The control-value theory of achievement emotions: an integrative approach to emotions in education. In: SCHUTZ, P.; PEKRUN, R. (ed.). Emotions in Education. San Diego, CA: Elsevier, 2007. p. 13-36.

PIAGET, J. Equilibration of cognitive structures. New York: Viking, 1977.

QUEIRÓS, P. Da formação à profissão: o lugar do estágio profisisonal. In: BATISTA, P.; GRAÇA, A.; QUEIRÓS, P. (ed.). O estágio profissional na (re)construção da identidade profissional em educação física. Porto: Editora FADEUP, 2014. p. 67-83.

ROSEMAN, I. J.; SMITH, C. A. Appraisal theory: overview, assumptions, varieties, controversies. In: SCHERER, K. R.; SCHORR, A.; JOHNSON, T. (ed.). Appraisal processes in emotion: theory, methods, research. New York: Oxford University Press, 2001.p. 3-19.

SCHUTZ, P. et al. Reflections on investigating emotion in educational activity settings. Educational Psychology Review, Germany, v. 18, n. 4, p. 343-360, 2006. https://doi.org/10.1007/s10648-006-9030-3

SFARD, A. On two metaphors for learning and the dangers of choosing just one. Educational Research, Thousand Oaks, v. 27, n. 2, p. 4-13, 1998. https://doi.org/10.2307/1176193

SIRNA, K.; TINNING, R.; ROSSI, T. Social process of health and physical education teachers' identity formation: reproducing and changing culture. British Journal of Sociology of Educayion, United Kingdom, v. 31, n. 1, p. 71-84, 2010. https://doi.org/10.1080/01425690903385501

SUTTON, R. E.; WHEATLEY, K. F. Teachers' emotions and teaching: a review of the literature and directions for future research. Educational Psychology Review, Germany, v. 15, n. 4, p. 327-358, 2003. https://doi.org/10.1023/A:1026131715856

TEN DAM, G.; BLOM, S. Learning through participation. The potential of school-based teacher education for developing a professional identity. Teaching and Teacher Education, Amsterdam, v. 22, n. 6, p. 647-660, 2006. https://doi.org/10.1016/j.tate.2006.03.003 
TIMOŠTŠUK, I.; KIKAS, E.; NORMAK, M. Student teachers' emotional teaching experiences in relation to different teaching methods. Educational Studies, United Kingdom,v. 42,n.3, p. 269-286,2016. https://doi.org/10.1080/03055698.2016.1167674 TIMOŠTŠUK, I.; UGASTE, A. Student teachers' professional identity. Teaching and Teacher Education, Amsterdam, v. 26, n. 8, p. 1.563-1.570, 2010. https://doi.org/10.1016/j.tate.2010.06.008

TIMOŠTŠUK, I.; UGASTE, A. The role of emotions in student teachers' professional identity. European Journal of Teacher Education, United Kingdom, v. 35, n. 4, p. 421-433, 2012. https://doi.org/10.1080/02619768.2012.662637

VEENMAN, S. Perceived problems of beginning teachers. Review of Educational Research, Thousand Oaks, v. 54, n. 2, p. 143-178, 1984. https://doi.org/10.3102/00346543054002143

VYGOTSKY, L. Mind in society: the development of higher psychological processes. Cambridge: Harvard University Press, 1978.

VYGOTSKY, L. A formação social da mente: o desenvolvimento dos processos psicológicos superiores. Tradução J. C. Neto, L. S. M. Barreto, S. C. Afeche. São Paulo: Martins Fontes, 1998.

WEISS, E.; WEISS, S. Doing reflective supervision with student teachers in a professional development school culture. Reflective Practice, United Kingdom, v. 2, n. 2, p. 125-154, 2001. https://doi.org/10.1080/14623940120071343

WENGER, E. Communities of practice: learning, meaning and identity. New York: Cambridge University Press, 1998.

WENGER, E.; MCDERMOTT, R.; SNYDER, W. Cultivating communities of practice: a guide to managing knowledge. Boston: Harvard Business School Press, 2002.

\section{SOBRE AS AUTORAS}

Patrícia Maria Silva Gomes é doutoranda em ciência do desporto pela Universidade do Porto (Portugal). Professora na mesma instituição. E-mail: patriciagomes.ms@gmail.com

Paula Maria Leite Queirós é doutoranda em ciência do desporto pela Universidade do Porto (Portugal). Professora na mesma instituição. E-mail: pqueiros@fade.up.pt

Paula Maria Fazendeiro Batista é doutoranda em ciência do desporto pela Universidade do Porto (Portugal). Professora na mesma instituição. E-mail:paulabatista@fade.up.pt 